\title{
miR-29a activates expression of $\alpha$-cardiac myosin heavy chain via $\beta 1$ thyroid hormone receptor in neonatal rats
}

\author{
Chengbin Wang, Ru He, Xiaohui Liu, Junhua Li, Rui Pan
}

Departments of Pediatrics, Xiangyang Central Hospital, Affiliated Hospital of Hubei University of Arts and Science, Xiangyang, Hubei, China

Submitted: 30 September 2019

Accepted: 24 November 2019

Arch Med Sci

DOI: https://doi.org/10.5114/aoms.2019.91495

Copyright $\odot 2019$ Termedia \& Banach

\section{Abstract}

Introduction: MicroRNAs (miRs) are small noncoding RNAs which are regulators of gene expression and also regulate the genes in heart tissues. The aim of the study was to evaluate the effect of miRs on the expression level of myosin heavy chain (MHC), which is responsible for regulation of cardiac functions in neonatal rat ventricular myocytes and mice.

Material and methods: The miRs were suppressed in neonatal rat ventricular myocytes using small interfering RNAs (siRNAs) against Dicer followed by evaluation of MHC levels. For in vivo study the C57 black/ 6 Jacksonian mice were subjected to the transverse aortic constriction (TAC) procedure.

Results: The Dicer siRNA suppressed the endogenous miRs and the $\alpha-M H C$ gene but failed to down-regulate the $\beta$-MHC. Among the 17 selected miRs, miR-29a was found to up-regulate the $\alpha-M H C$ gene significantly but not $\beta-M H C$. The expression of $\alpha-M H C$ was suppressed by silencing the expression of miR-29a. Bioinformatics study done by TargetScan suggested thyroid hormone receptor- $\beta 1$ (TR- $\beta 1$ ) as a potential target of miR-29a. Additionally, miR-29a was found to regulate the expression of $\alpha-M H C$ via TR- $\beta 1$ signaling. Conclusions: The findings of the present study indicated that miR-29a modulates expression of $\alpha$-the MHC gene by targeting TR- $\beta 1$ in cardiac cells. The study may provide a new direction for treating cardiac failure and cardiac hypertrophy.

Key words: miR-29a, $\alpha$-myosin heavy chain, thyroid hormone receptor- $\beta 1$, cardiac cells.

\section{Introduction}

MiRNAs (miRs) are small endogenous RNAs made up of 10 to 24 nucleotides via sequential processing of $I^{\text {ry }}$ RNAs responsible for inhibition of gene expression at the posttranscriptional level. The sequential processing of Iry transcripts is arbitrated by two enzymes, viz Dicer and Drosha. miRs have been found to play important roles in regulating cellular development, metabolism and immunity $[1,2]$. miRs are also reported to be negative regulators of genes which inhibit the translation or promote the degradation of target RNAs [3]. In a recent study, mice reported to be cardiac-specific dicer deficient showed cardiac abnormalities such as heart failure, sudden cardiac death and dilated cardiomyopathy [4, 5]. Microarray analysis on human cardiac tissues and rats has revealed

\author{
Corresponding author: \\ Rui Pan MD \\ Departments \\ of Pediatrics \\ Xiangyang Central \\ Hospital \\ Hubei University \\ of Arts and Science \\ Xiangyang, Hubei 441021 \\ China \\ E-mail: PrinceEricksonicr@ \\ yahoo.com
}


expression of miRs under various cardiac pathophysiology such as myocardial infarction, cardiac hypertrophy and cardiac failure [6-10]. An earlier study suggested involvement of specific miRs in the cardiac tissues of genetically modified mice, for example, mice deficient in miR-1-2 demonstrated cardiac arrhythmia and malformations from their birth [11]. miR-133a has been found to regulate proliferation of cardiomyocytes and suppress the smooth muscle gene expression in the cardiac muscles [12]. These studies suggest the potential role of miRs in cardiac pathophysiology and its development.

Contraction of cardiac muscles is dependent on expression levels of 2 cardiac myosin heavy chain genes (MHC) named $\alpha$ - and $\beta-M H C$. The expression of these two genes is regulated in an diametric manner via the pathological signals and the physiology [13]. It is also found that $\beta-M H C$ is over-expressed in cardiac failure and hypertrophy; hence identifying miRs that can regulate the expression of $\beta-\mathrm{MHC}$ may lead to new pathways in treating such cardiac disorders.

In a recent study, miR-208a, which is a cardiac-specific miRNA, was found to play a vital role in regulation of the $\beta-M H C$ gene in genetically modified mice showing over-expression of miR208a [14]. Thus, these kinds of studies confirm the usefulness of genetically modified animal models in determining involvement of any specific miRNA. However, in order to establish direct effects of specific miRs, in vitro studies are still needed as varied hemodynamic and hormonal effects can alter the levels of $\beta-M H C$ and blur the in vivo results [15].

Thyroid hormones have been found to play an important role in maintaining homeostasis of the cardiovascular system under conditions affecting heart rate, contractility, peripheral resistance and diastolic function via the genomic and non-genomic pathways [16]. These multiple actions of thyroid hormones are mainly executed via the thyroid receptors (TRs) [17]. Briefly, the expression of $\alpha-M H C$ is upregulated by T3 hormone, whereas the levels of $\beta-M H C$ are suppressed [17]. In addition, the changes in thyroid hormone signaling are linked to cardiac failure and cardiac hypertrophy $[16,17]$.

In the current study, we evaluated the expression of the MHC gene in rats transduced with $\mathrm{Di}$ cer SiRNA and 17 miRs, previously reported to be over-expressed in cardiac failure or hypertrophy [18]. The transduction was done in the neonatal rat ventricular myocytes (NRVMs) using transfecting vector. We demonstrated that suppression of Dicer, which is an important enzyme for biosynthesis of miRs, decreased the levels of miRs, leading to down-regulation of the $\alpha-M H C$ gene. We also reported that miR-29a was an important factor re- sponsible for regulation of $\alpha-M H C$ through the thyroid receptor- $\beta 1$ (TR- $\beta 1$ ) in NRVMs, and additionally we found that the levels of miR-29a were increased in the process of differentiation of stem cells or in the hypertrophic cardiac muscles of animals associated with over-expression of the $\alpha-M H C$ gene.

\section{Material and methods}

\section{Cell culture}

For the study, one-day-old Sprague-Dawley rats were used; the neonatal rat ventricular myocytes were isolated from them as described earlier [19] and were used for the study. The myocytes were cultured in Dulbecco's modified Eagle's medium (DMEM) supplemented with FBS (10\%), penicillin (1\%), streptomycin (1\%) in a 96-well plate at room temperature in presence of $\mathrm{CO}_{2}$. The DNA was transduced at 48 hours after seeding. The cell cultures were exposed to tri-iodothyronine.

For in vitro studies OLA derived embryonic stem cells ht7 (ES-ht7) (ATCC, USA) were used. The cells were subjected to DNA transduction; the cells were plated (marked as day ' 0 ') on plates coated with gelatin and media containing lentivirus and incubated for $24 \mathrm{~h}$. The effect of gene silencing in ES-ht7 cells was assessed by replacing the lentiviral vectors with phosphoglycerate kinase promoter (PGK). After this $3 \times 10^{4}$ cells/well were cultured into gelatin coated 6 -well plates devoid of leukemia inhibitory factor, embryonic bodies and feeder cells for seven days.

\section{Animals and transverse aortic constriction (TAC) procedure}

The animal studies were approved by the animal ethical committee of Xiangyang Central Hospital, Hubei China. All the protocols were in accordance with guidelines laid down by the animal review board of Hubei University of Arts and Science Xiangyang, Xiangyang, China. For the current study C57 black/6 Jacksonian mice were used and were subjected to TAC as reported earlier [20]. The fetal ICR mice were evaluated for vaginal plugs and after 14 days the heart tissue samples were obtained. The obtained samples were subjected to quantitative reverse transcription-PCR (qRT-PCR).

\section{Construction of vectors}

The miRNA expressing vectors were fabricated using a Block IT miRNAi expression kit (Invitrogen, USA) following the supplied instructions. The kit had a control miR-expressing vector, i.e. the control miR. For crafting anti-miR-29a, oligonucleotides having at least 3-6 sequences complementary to miR-29a were infixed into a pmiR-report vector at the miR-29a decay site. The siRNA vectors were 
fabricated from the pSINsi-U6 DNA. The oligonucleotide was introduced in the mU6 DNA at the $5^{\prime}$-end of BamHI site and $3^{\prime}$-end of the Clal site. The oligonucleotides for the control siRNA and specific genes are described in Table I. The oligonucleotide constructs were infixed into the pLenti6/V5-D-TOPO vector, and the TR- $\beta 1$ gene was cloned in the vector using the following primers: forward $5^{\prime}$-AGACAGAAAATGGCCTTCCAGCT-3', reverse 5'-TAGTCCTCAAAGACTTCCAAGA-3'. Amplifying and cloning the $3^{\prime} U T R$ region of the rat TR- $\beta 1$ in reported luciferase was done by primers (Table II) following the supplied instructions.

\section{DNA transduction and synthesis of lentivirus}

The lentivirus stock was produced in cells suitable for lentiviral production; we used 293T cells for transfection. After $48 \mathrm{~h}$ of transfection the medium containing virus was collected and filtered using a $0.45 \mu \mathrm{m}$ membrane filter. The lentiviral transfection was done by replacing the medium with medium containing virus supplemented with polybrene ( $5 \mu \mathrm{g} / \mathrm{ml})$; the resultant was submitted to cooling and centrifuged at $10000 \mathrm{rpm}$ for $15 \mathrm{~min}$ at $15^{\circ} \mathrm{C}$.
Table I. Oligonucleotide constructs for the control SiRNA

\begin{tabular}{|lc|}
\hline Genes & \multicolumn{1}{c|}{ Oligonucleotides } \\
\hline Dicer siRNA & 5'-GGAATGGACTCTGAGCTTA-3' $^{\prime}$ \\
\hline TR- $\beta 1$ siRNA & 5'-GGAAGCTGAAGAGAA-3' $^{\prime}$ \\
\hline siRNA & 5'-CAAGAGGACAGTACGCAAA-3' $^{\prime}$ \\
\hline Control siRNA & 5'-AATAATAATGGGGGGATCC-3' \\
\hline
\end{tabular}

\section{Extraction of RNA and qRT-PCR analysis}

For qRT-PCR analysis, total RNA was isolated from neonatal rat ventricular myocytes and heart tissues of ICR mice or C57 black/6 Jacksonian mice; the isolation was achieved using TRIzol reagent. The cDNA from total RNA $(5 \mu \mathrm{g})$ was synthesized using a High-Capacity cDNA Reverse Transcription Kit (Thermo Fisher USA) following the supplied procedure. For qRT-PCR studies, genes were submitted to amplification (30 cycles) using Promega PCR master mix (Promega, USA). The expression was normalized using GAPDH as a loading control. The primers used for the analysis are described in Table III.

Table II. Primers used for cloning the 3'UTR region

\begin{tabular}{|c|c|c|}
\hline \multirow[t]{2}{*}{ Receptors } & \multicolumn{2}{|c|}{ Primers } \\
\hline & Forward & Reverse \\
\hline TR- $\beta 1$ & 5'-GGACTAGTCAGACCATGCATAGGAAACACCAT-3' & 5'-CCCAAGCTTCACCCACATGCATTCCGTTTCCGAA-3' \\
\hline
\end{tabular}

Table III. Primers used for qRT-PCR analysis

\begin{tabular}{|c|c|c|}
\hline \multirow[t]{2}{*}{ Protein } & \multicolumn{2}{|c|}{ Primers } \\
\hline & Forward & Reverse \\
\hline GAPDH & 5'-TTGCCATCAACGACCCCTTC-3' & 5'-TTGTCATGGATGACCTTGGC-3' \\
\hline Dicer & 5'-ATGCGATTTTGGACTACCTCATAAC-3' & 5'-TCAG CTGTTAGGAACCTGAGGCTGG-3' \\
\hline ANF & 5'-TTCCTCGTCTTGGCCTTTTG-3' & 5'-CCTCATCTTCTACCGGCATCTTC-3' \\
\hline Rat BNP & 5'-TTCCGGATCCAGGAGAGACTT-3' & 5'-CCTAAAACAACCTCAGCCCGT-3' \\
\hline Mouse BNP & 5'-GCCAGTCTCCAGAGCAATTCA-3' & 5'-TGTTCTTTTGTGAGGCCTTGG-3' \\
\hline Rat $\alpha-M H C$ & 5'-GACACCAGCGCCCACCTG-3' & 5'-ATAGCAACAGCGAGGCTCTTTCTG-3' \\
\hline Rat $\beta-\mathrm{MHC}$ & 5'-GGAGCTCACCTACCAGACAGA-3' & 5'-CTCAGGGCTTCACAGGCATCC-3' \\
\hline Mouse $\alpha-M H C$ & 5'-GAGATTTCTCCAACCCAG-3' & 5'-TCTGACTTTCGGAGGTACT-3' \\
\hline Mouse $\beta-M H C$ & 5'-CTACAGGCCTGGGCTTACCT-3' & 5'-TCTCCTTCTCAGACTTCCGC-3' \\
\hline Nkx 2.5 & 5'-CAAGTGCTCTCCTGCTTTCC-3' & 5'-GGCTTTGTCCAGCTCCACT-3' \\
\hline Rat TR- $\beta 1$ & 5'-AGCCAGCCACAGCACAGTGA-3' & 5'-CGCCAGAAGACTGAAGCTTGC-3' \\
\hline Mouse TR- $\beta 1$ & 5'-AAGCCACAGGGTACCACTATGG-3' & 5'-GGAGACTTTTCTGAATGGTTCTTCTAA-3' \\
\hline DDR2 & 5'-AGTCAGTGGTCAGAGTCCACAGC-3' & 5'-CAGGGCACCAGGCTCCATC-3' \\
\hline
\end{tabular}

For evaluating the levels of miRs we used TaqMan MiRNA assays as per the provided instructions (Applied Biosystems). 


\section{RNA blotting analysis}

RNA blotting studies were done as reported earlier [21]. Briefly, from the total RNA a small fraction of RNA was isolated using a miR isolation kit (Thermo Fisher USA). About $5 \mu \mathrm{g}$ of the RNA fraction was subjected to separation on a polyacrylamide gel (10\%) by electrophoresis, then the resultant was transferred to a hybridization membrane using an electroblotter (Bio-Rad USA) at $4^{\circ} \mathrm{C}$ for $20 \mathrm{~min}$. The RNAs were cross linked using $0.1 \mathrm{M}$ each of 1-ethyl-3-(3-dimethylaminopropyl) carbodiimide and 1-methylimidazole for $2 \mathrm{~h}$ at $55^{\circ} \mathrm{C}$ at $\mathrm{pH} 8.4$.

\section{Luciferase reporter assay}

For the luciferase assay, the oligonucleotide constructs were transfected into the 293FT cells using transfecting reagent (Thermo Fisher USA). The neonatal rat ventricular myocytes were transfected using Lipofectamine 2000 reagent. The transfection was done using the firefly luciferase reporter gene $(0.1 \mu \mathrm{g})$, control plasmid Renilla reniformis $(0.01 \mu \mathrm{g})$, and miR-RNAi expression vector $(0.1 \mu \mathrm{g})$ for coding the specific miR or control. After $24 \mathrm{~h}$ of transfection, the luciferase activity was recorded using a dual reporter luciferase assay system. The results were normalized against luciferase activity of firefly.

\section{Western blot analysis}

Western blot analysis was done for studying the expression of proteins. For the study both incubated cells and heart tissues of $\mathrm{C} 57$ black/6 Jacksonian mice were homogenized in Tris buffer saline ( $\mathrm{pH} \mathrm{7.4).} \mathrm{The} \mathrm{buffer} \mathrm{before} \mathrm{use} \mathrm{was} \mathrm{supple-}$ mented with a protease inhibitor, $10 \mu \mathrm{M}$ sodium orthovanadate and $0.5 \mathrm{mM}$ sodium fluoride. The quantification of proteins was done by a protein estimation kit (Thermo Fisher USA). The proteins $(2-10 \mu \mathrm{g})$ were fractionated on NuPAGE Novex $10 \%$ Bis-Tris protein gels (Thermo Fisher USA), then the gels were transferred to nitrocellulose membranes. The membranes were blocked with non-fat milk (5\%) for $1 \mathrm{~h}$ followed by incubation with $\mathrm{I}^{\mathrm{ry}}$ antibody for $12 \mathrm{~h}$ at $4^{\circ} \mathrm{C}$. The membranes were rinsed using $0.05 \%$ Tris-phosphate buffer saline, and the formed complexes were subjected to analysis. The $I^{r y}$ antibodies used for the experiments were anti-Dicer (dilution, $1: 1000$ ) Santa Cruz Biotech, anti-GAPDH (dilution, $1: 1000)$ Santa Cruz Biotech, anti- $\alpha$ MHC (dilution, $1: 20000$ ) Abcam USA, $\beta$-MHC (dilution, $1: 20000$ ) Sigma Aldrich USA, anti-TR- $\beta 1$ (dilution, 1 : 500) Santa Cruz Biotech USA and anti-RXR $\alpha$ (dilution, $1: 500$ ). The secondary antibodies used for the study were antimouse, anti-goat and anti-rabbit IgG at dilution $1: 2000$.

\section{Statistical analysis}

The results were presented as mean \pm standard error of mean (SEM). The comparisons between the groups were done by one-way ANOVA or unpaired Student's $t$ test, whichever was appropriate. The $p$-values $<0.05$ were considered significant.

\section{Results}

\section{Dicer siRNA suppresses miRNAs and} $\alpha-M H C$ in neonatal rat ventricular myocytes

To study the effect of miRs on levels of MHC, we opted to suppress the function of endogenous miRs in neonatal rat ventricular myocytes. As we have elaborated about the importance of Dicer for synthesis of miRNA, it was speculated that the suppression of Dicer could lead to loss of function of miRNAs. The neonatal rat ventricular myocytes were subjected to transduction with siRNA with the aid of a lentiviral vector; which resulted in suppression of protein and Dicer mRNA under conditions in presence of serum (Figures $1 \mathrm{~A}, \mathrm{~B}$ ).

The expression levels of both $\alpha$ - and $\beta-M H C$ were evaluated in neonatal rat ventricular myocytes transduced with Dicer siRNA. We observed that the transduction of Dicer siRNA downregulated the mRNA as well as protein levels of $\alpha-M H C(p<0.01)$ but not of $\beta$-MHC compared to respective control siRNA (Figures $1 \mathrm{C}, \mathrm{D}$ ). These findings suggested that the loss of function of miRs could lead to suppression of $\alpha-M H C$ in neonatal rat ventricular myocytes cultured with serum. We also found some specific miRs which can regulate the expression of $\alpha-M H C$.

Next, to find the miRs that can increase the expression of $\alpha-M H C, 17$ selected miRs were transduced individually in the neonatal rat ventricular myocytes, after which $\alpha$-MHC mRNA levels were evaluated under serum containing conditions. Among the 17 selected miRs for the study, 5 were indentified earlier to be muscle specific (miR-208a, miR-208b, miR-133a, miR-133b and miR-499) [14, $12,22,23]$. Additionally, 12 other miRs were included as they were reported to be over-expressed in some in vivo and in vitro cardiac models, malfunctioned cardiac tissues, cardiac failure and hypertrophy, and some miR microarray analysis also suggested them [18]. The results of qRT-PCR indicated multiple miRs increasing the levels of $\alpha-M H C$ but not significantly; however, we found that miR29a increased the levels of significantly (Figure 1 E). The findings hence confirmed potential involvement of miR-29a in regulation of $\alpha-M H C$ under the present experimental conditions.

\section{miR-29a up-regulates expression of $\alpha-M H C$ gene in neonatal rat ventricular myocytes}

To find out whether miR-29a was over-expressed under altered cardiac conditions accom- 
A

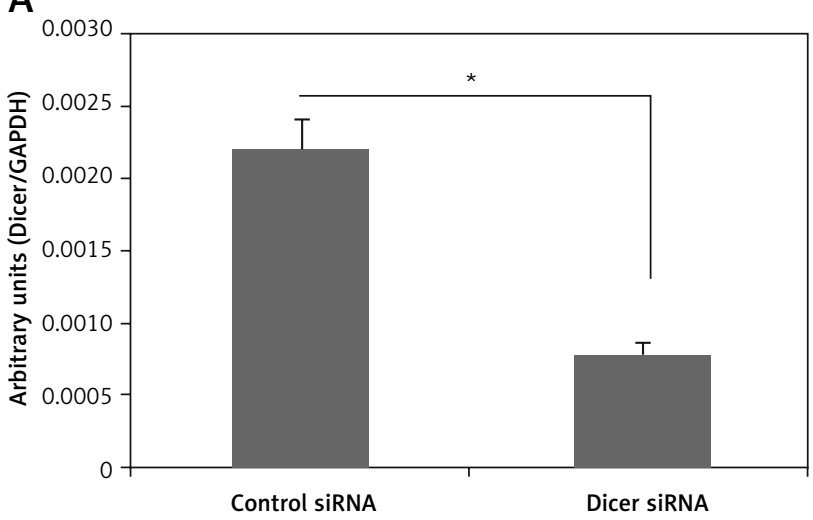

C

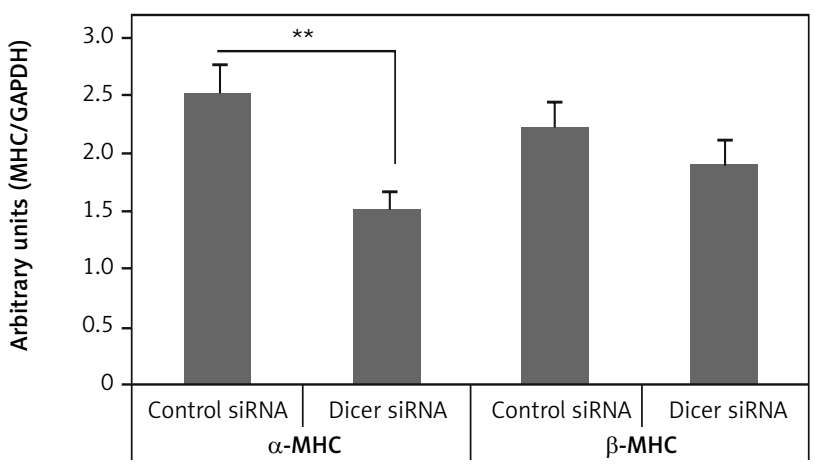

B

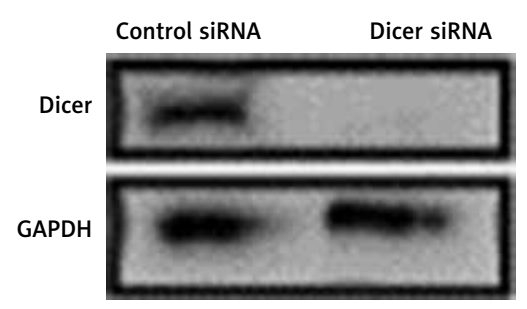

D

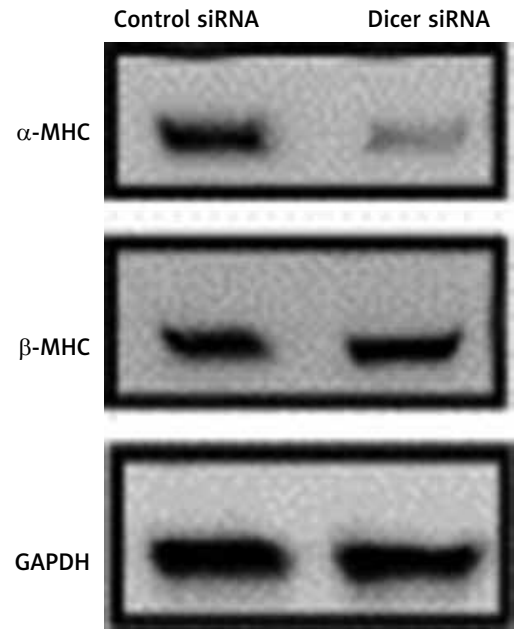

$E$

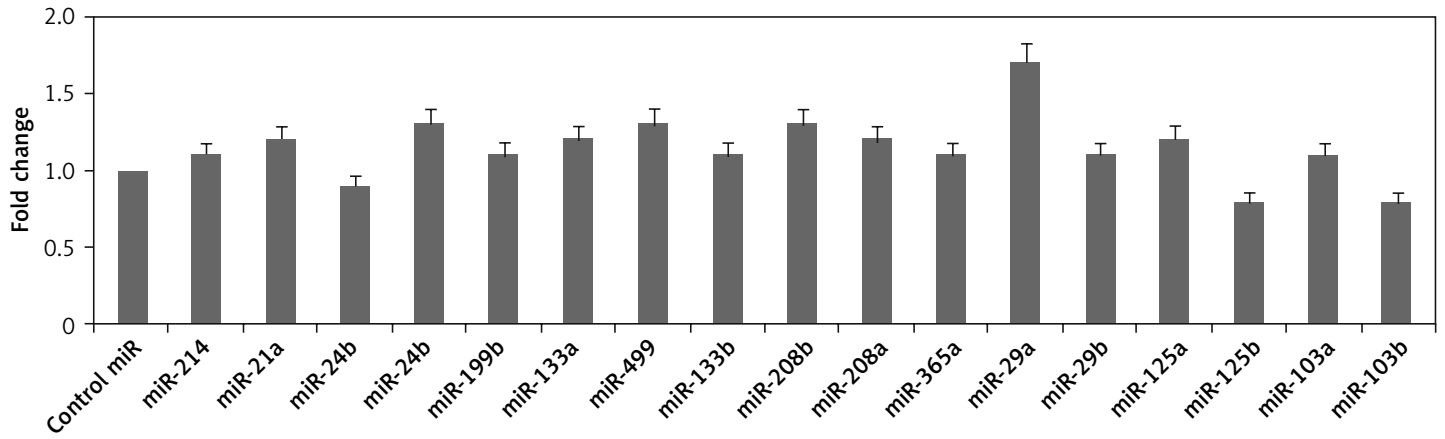

Figure 1. Dicer siRNA suppresses the expression of endogenous miRs and $\alpha-M H C$. The evaluation was done 72 hours (A to $\mathbf{C}$ and $\mathrm{E}$ ) or $96 \mathrm{~h}$ (D) after transfection with Dicer siRNA or control and miRs or miR-control in the NRVMs using lentiviral vector. The NRVMs used in the study were seeded under serum rich conditions. A, B - mRNA and protein levels of Dicer. C, D - qRT-PCR (C) and Western blot (D) analysis of mRNA and protein levels of $\alpha$ - and $\beta-M H C$. E - Results of qRT-PCR analysis for mRNA levels of $\alpha-M H C$ in NRVMs transduced with miRNAs compared to control miR

Data are presented as mean $\pm S E$ for $n=3 .{ }^{*} P<0.05,{ }^{* *} p<0.01$ compared to respective controls.

panied by the upregulated $\alpha-M H C$ gene, levels of miR-29a were evaluated in Dahl salt-sensitive rat hearts, which are reported to show high salt induced hypertensive hypertrophy after 11 weeks followed by cardiac failure at 17 weeks. It was observed that in the cardiac tissues of Dahl salt-sensitive rats given a high salt diet for eleven or seventeen weeks, the gene expression levels of $\alpha-M H C$ were upregulated along with upregulated mRNA levels of BNP and ANF (potential markers of cardiac pathology) (Figures 2 A, B). Additionally, miR-29a was over-expressed under low salt (LS) and high salt (HS) diet in cardiac tissues of Dahl salt-sensitive rat (Figure $2 \mathrm{C}$ ), demonstrating a link between miR-29a and $\alpha-M H C$ gene expression. 

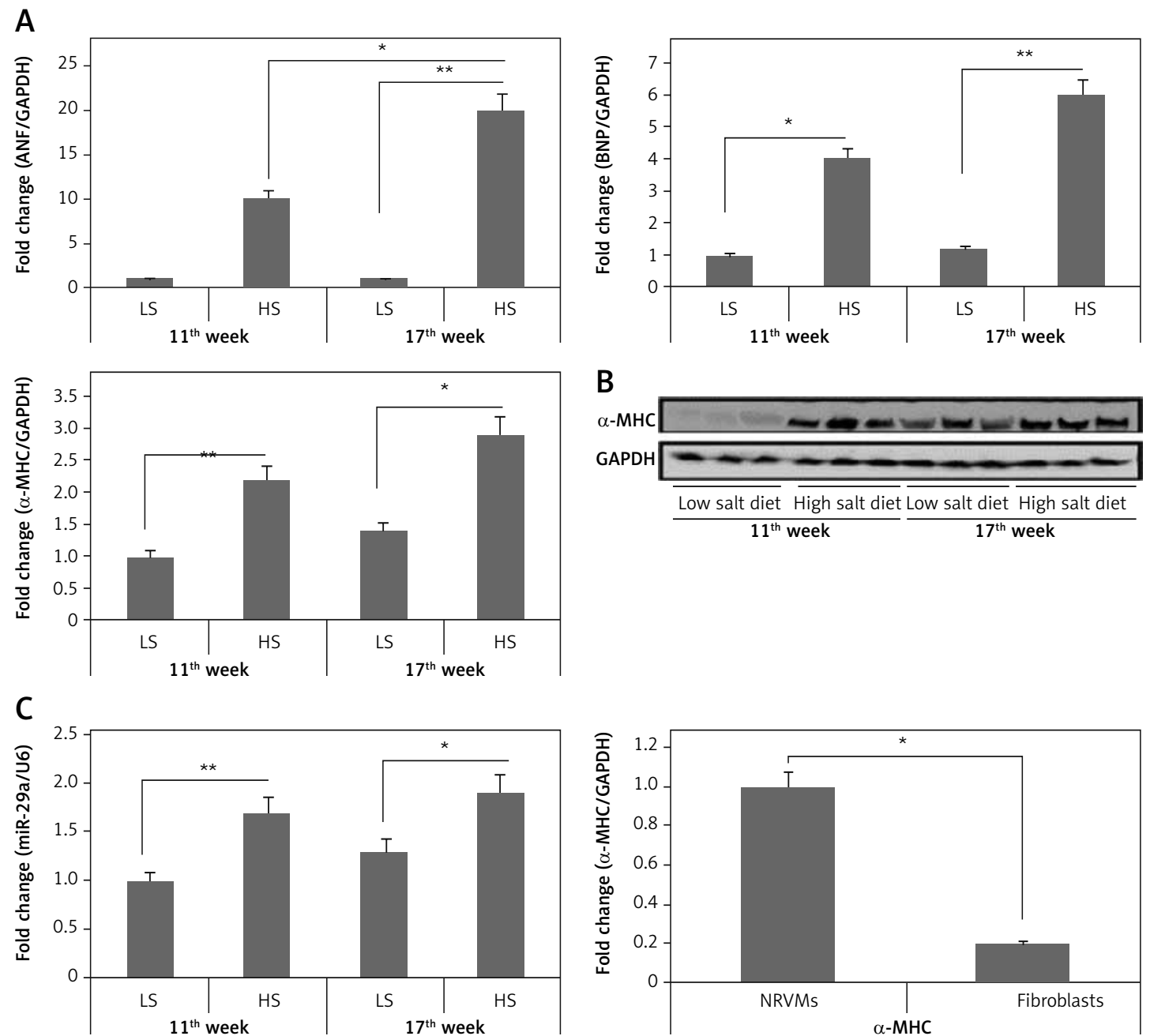

D

$\mathrm{E}$
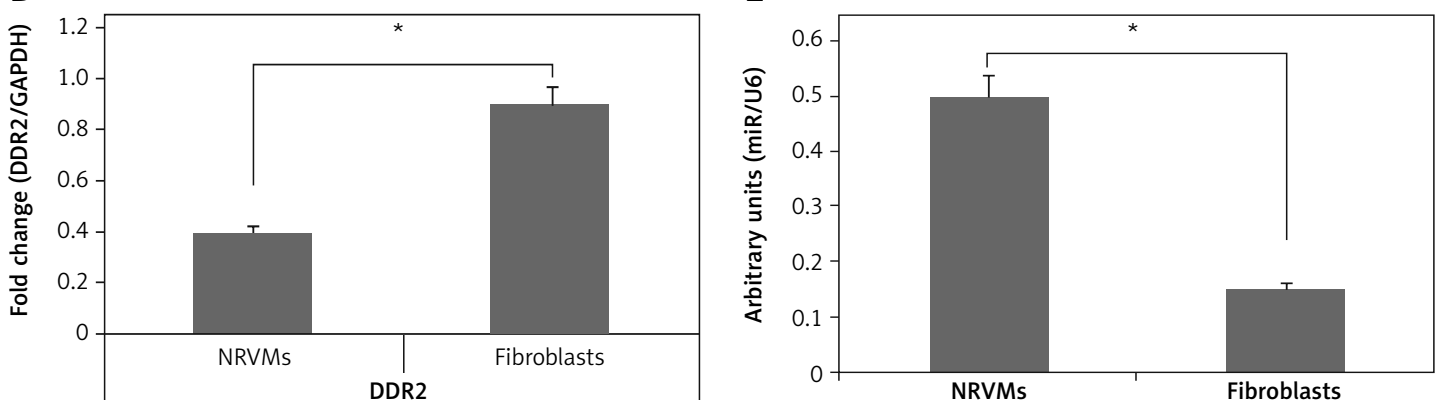

Figure 2. miR-29a increases expression of the $\alpha-M H C$ gene. A - Shows qRT-PCR analysis for levels of ANF, BNP and $\alpha-M H C, C$ - shows levels of miR-29a compared to GAPDH as loading control in heart tissues of salt-sensitive rats observed after 11 and 17 weeks. B - Western blot analysis for levels of $\alpha$-MHC expression in low salt and high salt diet conditions. GAPDH was used as loading control. D - mRNA expression of $\alpha-M H C$ and DDR2 in fibroblasts and NRVMs; the values are mean and relative to untreated NRVMs. E - qRT-PCR analysis showing miR-29a expression levels in NRVMs and fibroblasts. F-H - After $72 \mathrm{~h}$ of transduction with miR-29a or control miR

The results are means $\pm S E\left({ }^{*} p<0.05,{ }^{* *} p<0.01,{ }^{* * *} p<0.001\right)$.

To evaluate whether miR-29a was expressed in cardiac myocytes endogenously, we assessed miR-29a levels in cardiac fibroblasts and neonatal rat ventricular myocytes. The optimum isolation of both types, i.e. fibroblasts and neonatal rat ventricular myocytes, was confirmed by evaluating the mRNA levels of $\alpha-M H C$ and discoidin domain receptor 2 (DDR2) (Figure 2 D). We found that miR-29a was expressed significantly more highly $(p<0.05)$ in neonatal rat ventricular myocytes compared to the fibroblasts (Figure $2 \mathrm{E}$ ). Also over-expression in myocytes affirmed that 
$\mathrm{F}$

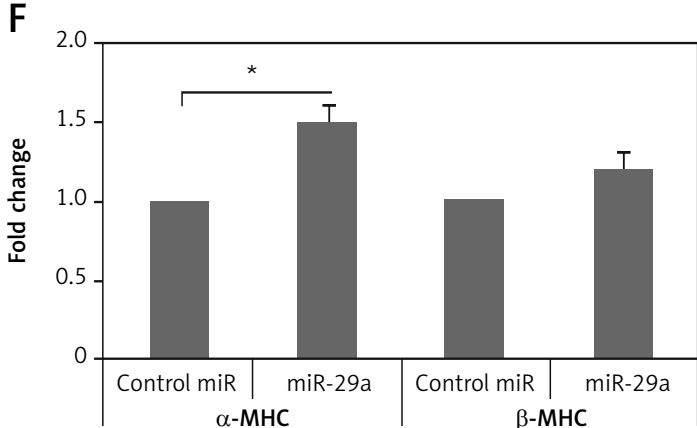

$\mathrm{H}$

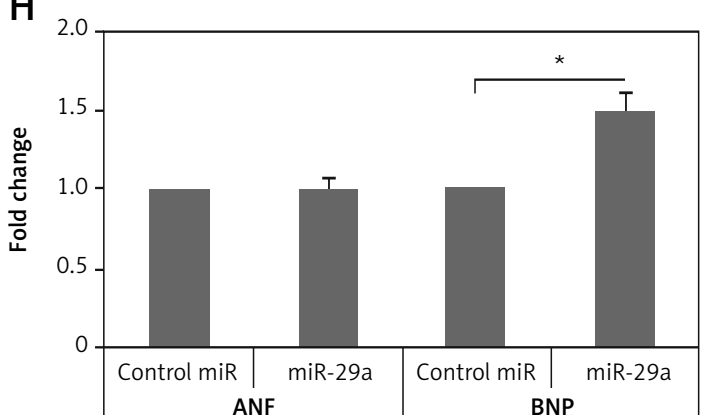

miR-29a could lead to upregulation of $\alpha-M H C$ significantly $(p<0.05)$ and not the $\beta$-MHC gene at protein as well as at mRNA levels under serum enriched conditions (Figures $2 \mathrm{~F}, \mathrm{G}$ ). miR-29a could also up-regulate the mRNA levels of BNP but not of ANF (Figure $2 \mathrm{H}$ ). The results hence suggested that the miR-29a mediated upregulation of the $\alpha-M H C$ gene may be a direct effect of miR-29a rather than due to an IIry change to heart pathology induced by miR-29a.

Non-functioning miR-29a decreases $\alpha-M H C$ protein levels in neonatal rat ventricular myocytes

To evaluate the direct consequences of miR-29a on regulation of the $\alpha-M H C$ gene, the protein levels of $\alpha-M H C$ were evaluated in neonatal rat ventricular myocytes in which the functioning of miR29 a was suppressed. The neonatal rat ventricular myocytes were transfected with a lentiviral vector having a 3'UTR region with 3 to 6 tandem miR29a decoy sequences; these were complementary with the sequence in miR-29a linked to a luciferase reporter gene as reported earlier [24-26]. The decoy sequences parted the endogenous miR29a. When miR-29a was transfected in the 293T cells using a miR-29a decoy, it resulted in decrease of luciferase activity significantly compared to control miR $(p<0.001)$ (Figure $3 \mathrm{~A}$ ). It was also demonstrated that miR-208b, miR-133a and miR$24 \mathrm{~b}$ did not affect the luciferase activity (Figure $3 \mathrm{~A}$ ). Then, the neonatal rat ventricular myocytes were transfected with miR-29a decoys; this trans-
G

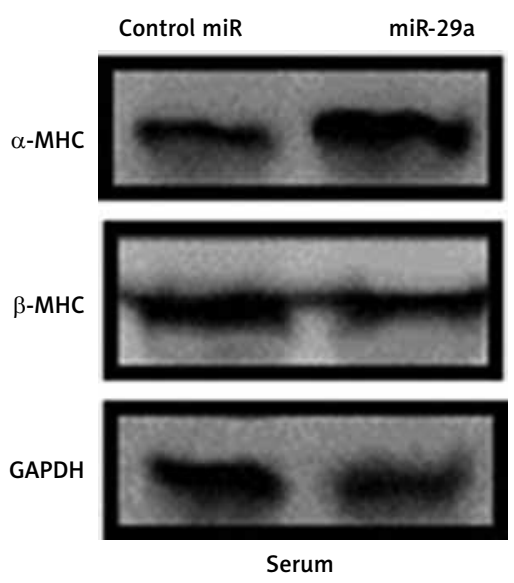

Figure 2. Cont. F, G - miR levels of both $\alpha$ - and $\beta-M H C . H-m R N A$ levels of ANF and BNP

The results are means \pm SE $\left({ }^{*} p<0.05,{ }^{* *} p<0.01\right.$, $\left.{ }^{* * *} p<0.001\right)$.

fection caused decrease in luciferase activity significantly compared to the control decoy $(p<0.01)$ (Figure $3 \mathrm{~B}$ ). These findings suggested that miR29 a decoys could bind specifically to the endogenous miR-29a. We also found that upon transducing miR-29a decoys in the neonatal rat ventricular myocytes using lentiviral vectors, $\alpha-M H C$ protein levels were down-regulated, but the levels of $\beta-M H C$ remained unaltered under serum enriched conditions (Figures $3 \mathrm{C}-\mathrm{E}$ ). These results confirmed that miR-29a is involved in regulation of the $\alpha-M H C$ gene in neonatal rat ventricular myocytes. MiR-208a and miR-499 are reported to be inducers of MHC [14, 23]. To evaluate the involvement of inducing miRs in regulation of $\alpha-\mathrm{MHC}$ a study similar to miR-29a was done using the miR-208a decoy. The miR-208a decoy binds to endogenous miR-499 and miR-208a (Figures 3 A, B). A decoy works by binding a specific miR which is complementary to the sequences in the decoy; miR-499 and -208a have been found to have similar sequences and could bind the miR-208a decoy [26].

\section{Bioinformatics studies for prediction of target of miR-29a}

To identify the targets of miR-29a which can regulate the expression of $\alpha-M H C$, bioinformatics analysis was done by TargetScan for identifying potential targets of miR-29a. We speculated that upregulation of miR-29a could suppress the target gene which can regulate the expression of $\alpha-M H C$ negatively; this might lead to upregulation 
A

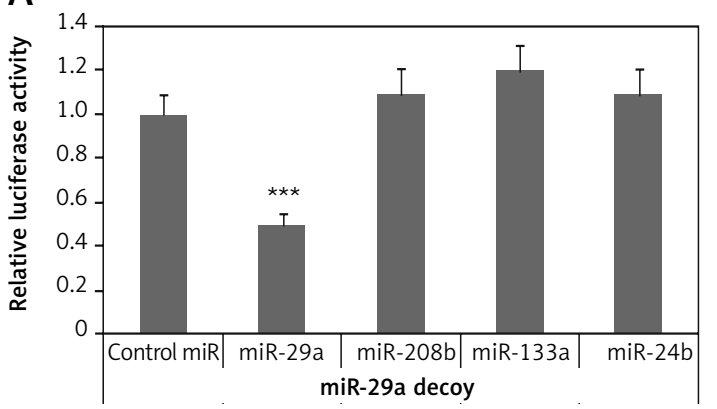

C

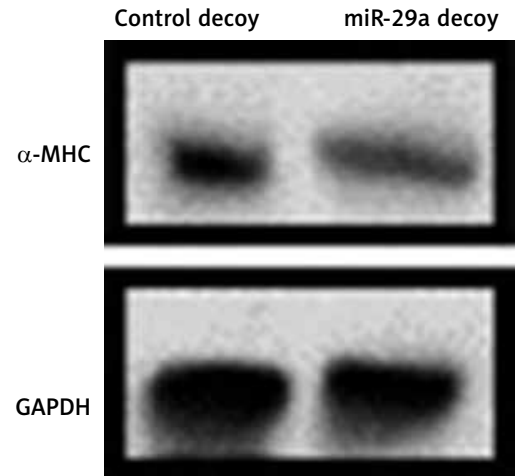

$E$

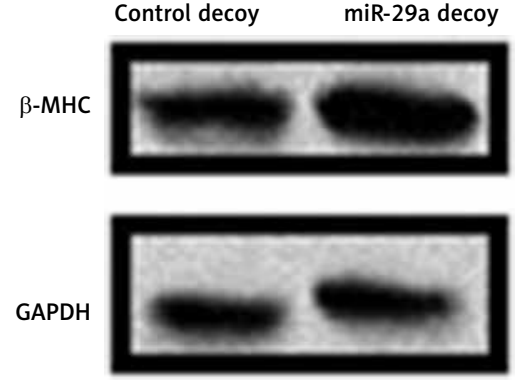

B

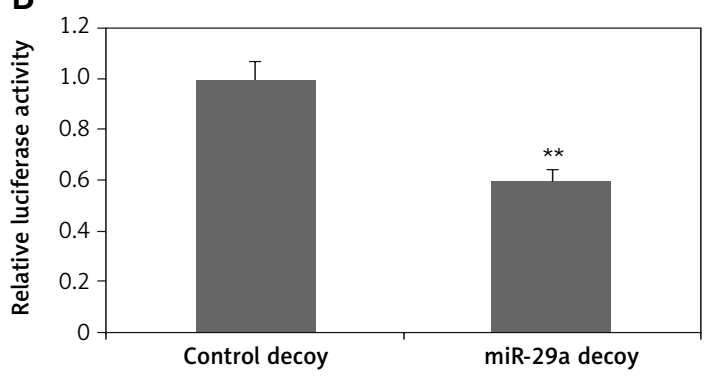

D

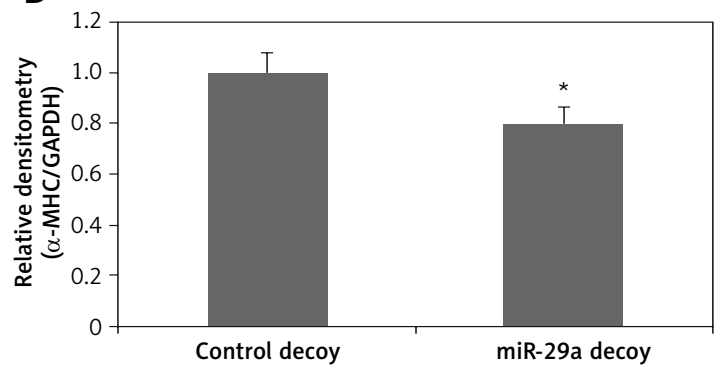

Figure 3. miR-29a decoy suppresses protein levels of $\alpha-$ MHC. A $-293 T$ cells received transfection of luciferase miR-29a decoy construct along with miR plasmid or control-miR. B - miR-29a and control decoy were transfected in the NRVMs; the results are relative to control. C-E - Assays were done $72 \mathrm{~h}$ post transfection. The NRVMs were transduced with miR-29a decoy and protein expression of $\alpha$ - and $\beta-\mathrm{MHC}$ was evaluated

The results are means $\pm S E\left({ }^{*} p<0.05,{ }^{* *} p<0.01,{ }^{* *} p<0.001\right)$.

of $\alpha-M H C$. It was expected that the transcription factors responsible for negative regulation of $\alpha-M H C$ or its associated co-regulators would be involved in upregulation of $\alpha-M H C$. Literature has suggested multiple factors which can bind to the rat $\alpha-M H C$ promoter [27], TargetScan predicted TR- $\beta 1$ to be one of the targets of miR-29a (Figure 4 A). TR- $\beta 1$ negatively regulates the transcription of $\alpha-M H C$ by binding to thyroid hormone response element (TRE) [28]. Further, the 3'UTR of TR- $\beta 1$ was transfected into the luciferase construct which was transduced into 293 T cells and the cytomegalovirus miR-29a decreased the luciferase activity of the construct (Figure $4 \mathrm{~A}$ ). The results also demonstrated that the luciferase activity decreased significantly for TR- $\beta 1$ transfected 3'UTR reporter $(p<0.05)$ (Figure 4 B). It was however noted that the luciferase activity remained unaffected in the mutant reporters by miR-29a (Figures $4 \mathrm{~A}, \mathrm{~B})$. These results demonstrated that the binding sites of miR-29a in the 3'UTR region of TR- $\beta 1$ could lead to translational suppression due to miR-29a.

\section{Thyroid hormone receptor- $\beta 1$ is a potential} target of miR-29a

To confirm whether miR-29a specifically targets TR- $\beta 1$, the expression of TR- $\beta 1$ was studied in neonatal rat ventricular myocytes or $293 \mathrm{~T}$ cells transfected with miR-29a or its decoy. We found that miR-29a down-regulated the protein levels of TR- $\beta 1$ without altering the mRNA levels in the neonatal rat ventricular myocytes. We also found that the miR-29a decoy enhanced the protein levels of TR- $\beta 1$ (Figures $5 \mathrm{~A}, \mathrm{~B}$ ). Similar results were observed in the case of $293 \mathrm{~T}$ cells (Figure $5 \mathrm{C}$ ). These outcomes suggested that TR- $\beta 1$ is a favorable target of miR-29a in human as well as in rat cells.

\section{miR-29a regulates levels of $\alpha-M H C$ protein via TR- $\beta 1$}

To evaluate whether miR-29a is involved in regulation of $\alpha-M H C$ expression through TR- $\beta 1$, we subjected the neonatal rat ventricular myocytes to miR-29a or its decoy followed by treat- 
A
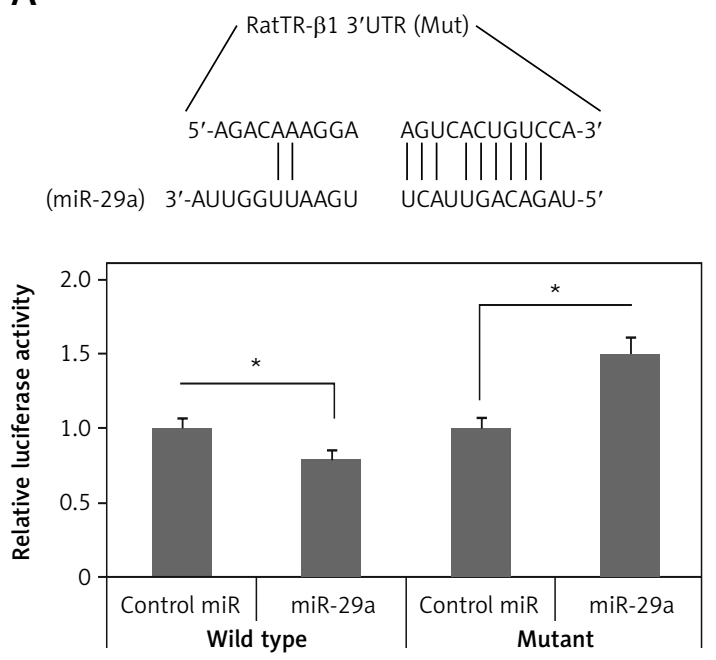

B

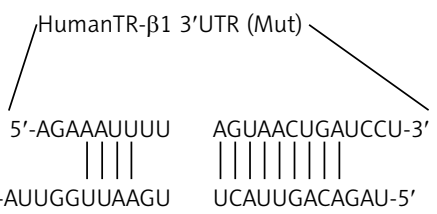

Figure 4. Prediction of target for miR-29a in the $\alpha-M H C$ promoter. A - Binding sites of miR-29a in the rat TR- $\beta 1$ 3'UTR. B - Binding sites of miR-29a in the human TR- $\beta 1$ 3'UTR

ment with tri-iodothyronine (T3) and the protein levels of $\alpha$-MHC were assessed. We found that the treatment of $\mathrm{T} 3(10 \mathrm{nM})$ in neonatal rat ven- tricular myocytes upregulated the expression of $\alpha-M H C$ significantly and down-regulated the levels of $\beta$-MHC (Figure $6 \mathrm{~A}$ ). These findings were in
A

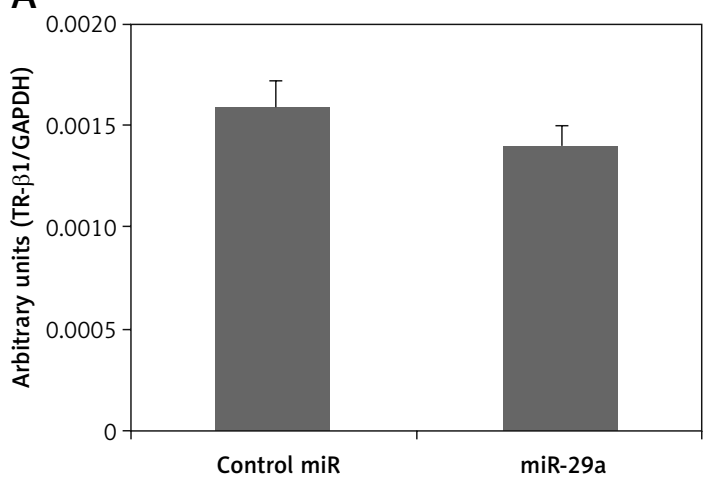

B

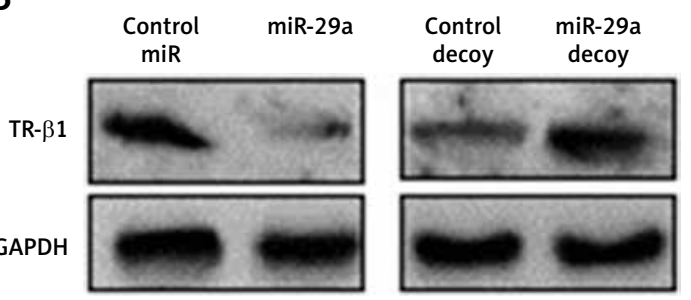

C

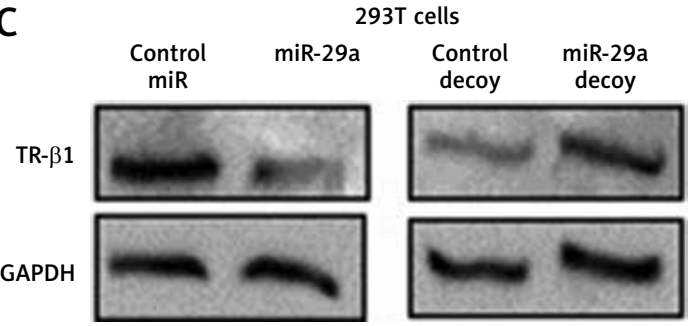

Figure 5. TR- $\beta 1$ is the favorable target of miR-29a. A-C - Assays were done $72 \mathrm{~h}$ after transduction with lentiviral vector into the NRVMs and 293T cells. mRNA and protein levels of TR- $\beta 1$ were evaluated by qRT-PCR (A) and western blot analysis (B and C)

A

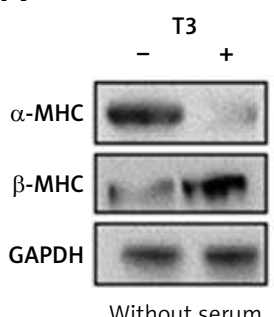

Without serum

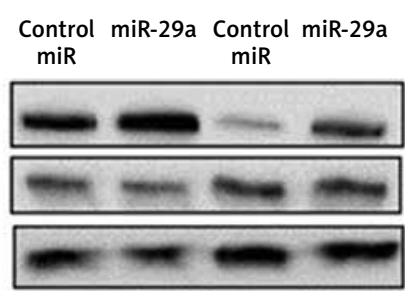

Without serum Without serum +

$$
\mathrm{T} 3
$$

B

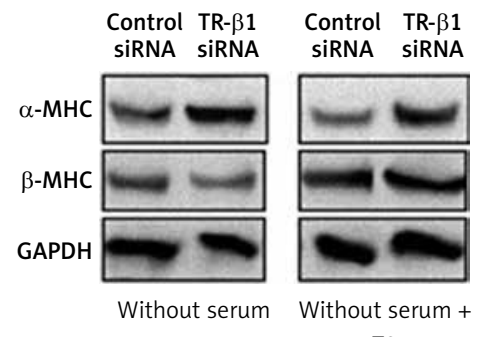

$\mathrm{T} 3$

Figure 6. miR-29a regulates protein levels of $\alpha-M H C$ via TR- $\beta 1$. After $24 \mathrm{~h}$ of transduction, treatment with T3 $(10 \mathrm{nM})$ was continued for $48 \mathrm{~h}$. Western blot analysis of $\alpha$ and $\beta$ MHC was done in NRVMs transduced with miR-29a and control miR (A) and control siRNA and TR- $\beta 1$ siRNA (B) 
A

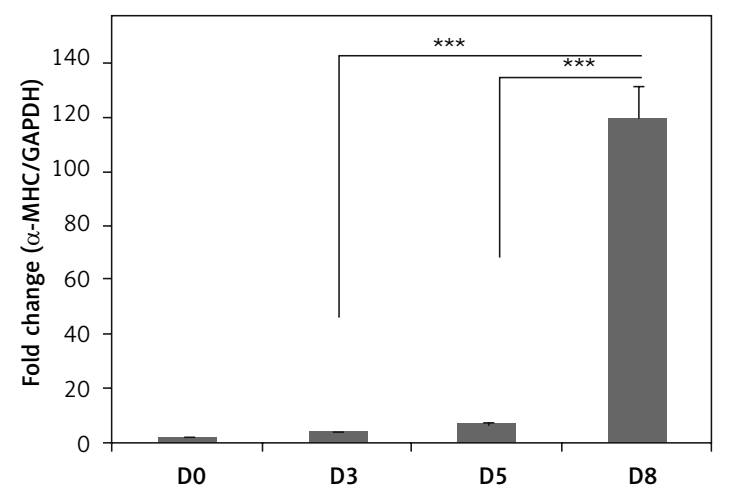

C

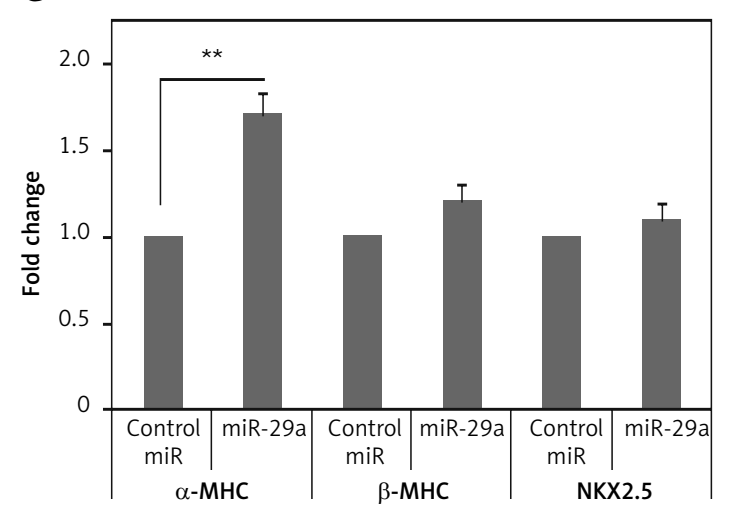

$\mathrm{E}$
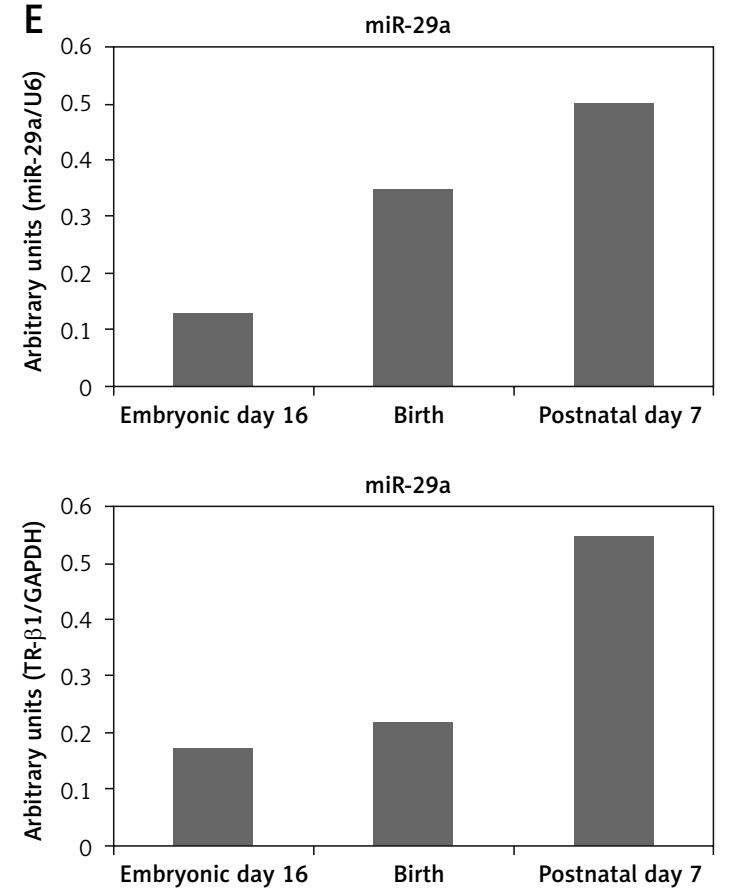

B

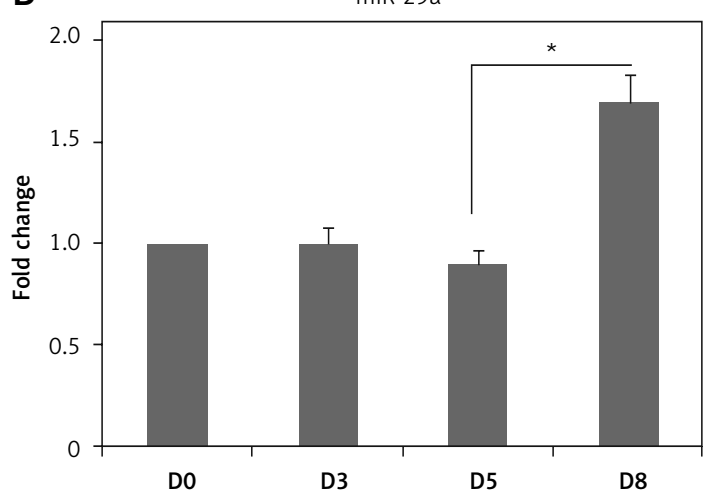

D
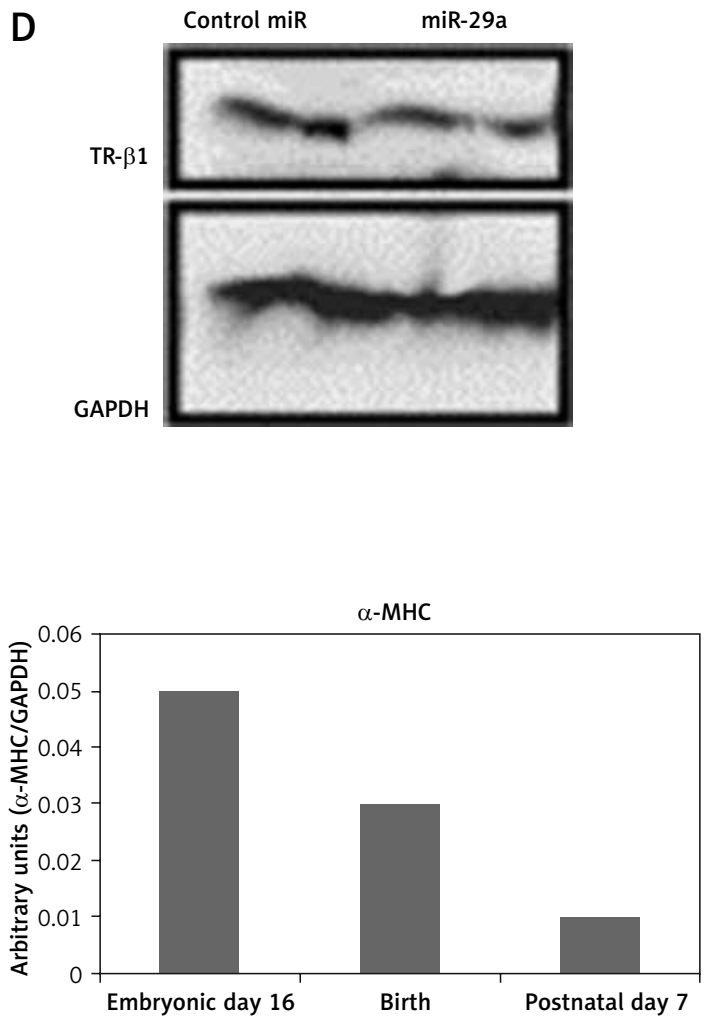

Figure 7. Up-regulation of miR-29a increases the gene expression of $\alpha-M H C$ in mouse ES cells. qRTPCR analysis of $\alpha$-MHC mRNA (A) or miR-29a levels during the differentiation of ES cells in mouse (B). Both the levels of $\alpha-M H C$ mRNA and miR-29a were represented relative to levels at day $0 . C-q R T$ PCR analysis for mRNA levels of $\alpha$ - and $\beta-M H C$ and NKX2.5 were presented. D - protein levels of TR- $\beta 1$ by western blot analysis in ES cells from mouse at the eighth day after transduction with miR-29a or control miR. E - qRT-PCR analysis of mRNA levels of miR-29a or $\alpha-M H C$ and TR- $\beta 1$ in heart tissues at the sixteenth day in the embryonic mouse, at the birth and at postnatal day 7

The results are means $\pm S E\left({ }^{*} p<0.05,{ }^{* *} p<0.01\right.$, $\left.{ }^{* * *} p<0.001\right)$. 
agreement with a study reported earlier in which $\mathrm{T} 3$ induced the expression of $\alpha-\mathrm{MHC}$ in cardiac myocytes [29]. Up-regulated miR-29a attenuated the effect of T3, which caused an increase in protein levels of $\alpha-M H C$ but did not alter the expression of $\beta-M H C$ (Figure $6 \mathrm{~A}$ ). The results after TR- $\beta 1$ siRNA treatment were also similar (Figure $6 \mathrm{~B}$ ), hence suggesting regulation of the $\alpha-M H C$ gene by miR-29a through TR- $\beta 1$.

\section{Up-regulation of miR-29a increases the $\alpha-M H C$ gene in mice ES cells}

To study the physiological effect of miR-29a on TR- $\beta 1$-mediated regulation of $\alpha-M H C$ in mice, we evaluated the expression of miR-29a and MHC in cardiac tissues of mice ES cells at the stage of differentiation into cardiomyocytes. The ES cells were incubated on gelatin-coated plates and allowed to differentiate for 8 days. The mRNA levels of $\alpha-M H C$ in mice ES cells increased significantly between day 5 and 8 (Figure 7 A) [29], whereas the levels of miR-29a remained unchanged until the $5^{\text {th }}$ day, but increased up to 1.5 times in between the $5^{\text {th }}$ and the $8^{\text {th }}$ day (Figure 7 B). Additionally, over-expression of miR-29a in ES cells of mice increased the mRNA levels of $\alpha-M H C$, but failed to alter expression $\beta-M H C$ or NKX2.5, which is an indicator of cell differentiation of cardiac cells, and decreased the protein levels of TR- $\beta 1$ (Figures 7 C, D). These outcomes suggested that the over-expression of miR-29a could up-regulate levels of $\alpha-M H C$ via TR- $\beta 1$ without affecting the cell differentiation of mice ES cells. To investigate the physiological role of miR-29a in development of cardiac tissues, the levels of miR-29a, $\alpha-M H C$ and TR- $\beta 1$ were studied. The outcomes demonstrated that, during the process of cardiac development, the mRNA levels of miR-29a and TR- $\beta 1$ increased progressively, whereas the levels of $\alpha-M H C$ decreased (Figure $7 \mathrm{E}$ ).

\section{miR-29a is over-expressed in cardiac tissues of mice exposed to TAC}

To confirm the role of miR-29a in vivo, the expression levels of miR-29a, $\alpha-M H C$ and TR- $\beta 1$ were evaluated in cardiac tissues of mice treated with TAC, which causes cardiac hypertrophy in mice. The results demonstrated that expression of $\alpha-M H C$ increased and that of TR- $\beta 1$ was decreased during the time interval between the $3^{\text {rd }}$ and $4^{\text {th }}$ week of TAC exposure (Figures 8 A, B). Additionally, expression of miR-29a was up-regulated during the $1^{\text {st }}$ and $4^{\text {th }}$ week of TAC treatment (Figure $8 \mathrm{C}$ ). These outcomes indicated that expression of miR-29a could be linked to development of cardiac hypertrophy via regulation of $\alpha-M H C$ through TR- $\beta 1$.

\section{Discussion}

A number of studies have investigated the role of miRs in the cardiovascular system. However, it is difficult to identify a target specific miR from multiple miRs as these micro-molecules can alter several target genes simultaneously. In in vivo analysis, a number of factors such as hemodynamics, cytokines and hormones can affect gene regulation in cardiac cells, which makes the process of evaluating the effect of a specific miR difficult. In the present study, we attempted to evaluate the direct effect of miRs on regulation of cardiac genes using the $I^{r y}$ cultures of neonatal rat ventricular myocytes. We selected neonatal rat ventricular myocytes as these cells have a minimal effect of environmental factors or any possible interactions from the other cellular components.

In the present study, we attempted to suppress the miRNA function neonatal rat ventricular myocytes via siRNA against an enzyme named Dicer which is necessary for biosynthesis of miR. We also studied the effects of target miRNA on expression levels of a cardiac specific gene, i.e. MHC.

Earlier in a study, targeted deletion of Dicer in the heart leads to dilated cardiomyopathy and heart failure by targeting $\alpha-M H C$ [30]. The outcomes of the present study suggested that Dicer siRNA leads to down-regulation of $\alpha-M H C$. These variations in outcomes may be due to differences in expression of $\alpha-M H C$ in the perinatal and fully grown mice or may be from the hormonal and the hemodynamic effects in vivo [31].

The current findings demonstrate a novel role of miR-29a as an activator of the $\alpha-M H C$ gene. miR-208a and miR-499 were identified as established activators of MHC genes [26, 32]; here the transduction showed no significant alterations in expression of $\alpha-M H C$; the reduction of miR-29a levels was significant compared to that shown by miR-208a and miR-499 in neonatal rat ventricular myocytes transfected with Dicer siRNA. Additionally, the miR-29a decoy decreased the protein levels of $\alpha-M H C$, whereas the decoy of miR-208a failed to do the same. Hence the outcomes confirmed that the effects of miR-29a were significant compared to those of miR-208a and miR-499, which are muscle-specific miRNAs and are known to play important roles in regulation of MHC levels [32].

In the present study we found that miR-29a could be a modulator of the thyroid hormone receptor pathway in the $\alpha-M H C$ gene. Also the expression of MHC gene is potentially modulated by thyroid hormone and receptors. The results suggested that TR- $\beta 1$ regulates the expression of $\alpha$-MHC in neonatal rat ventricular myocytes, which was in agreement with an earlier study [33]. The present results also suggested that levels of $\beta-M H C$ remained unaffected by TR- $\beta 1$ in neonatal 
A
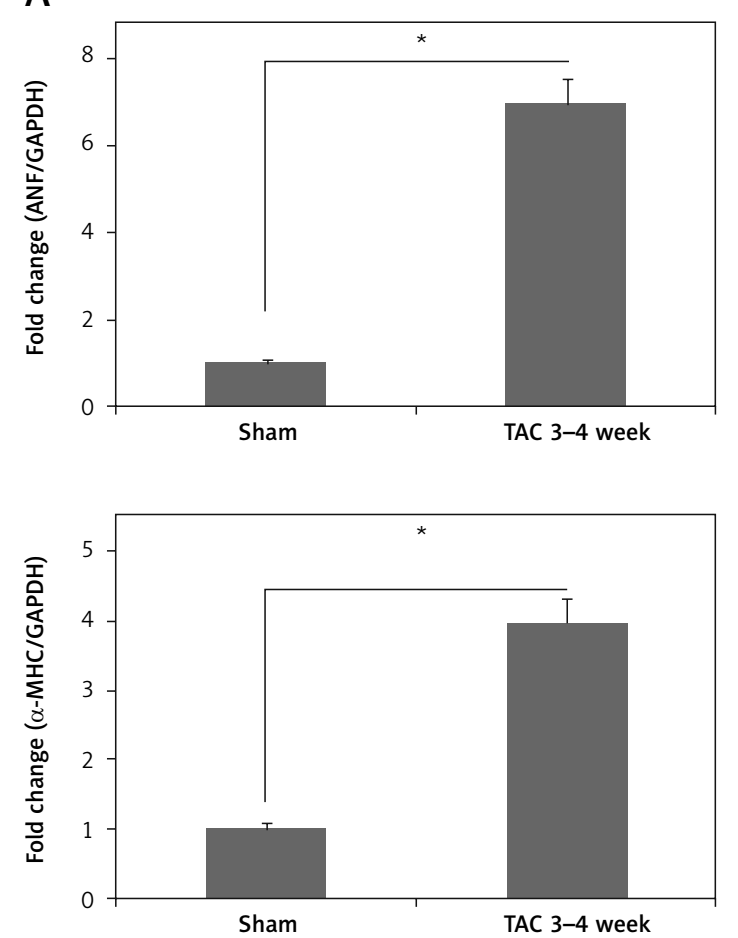

C

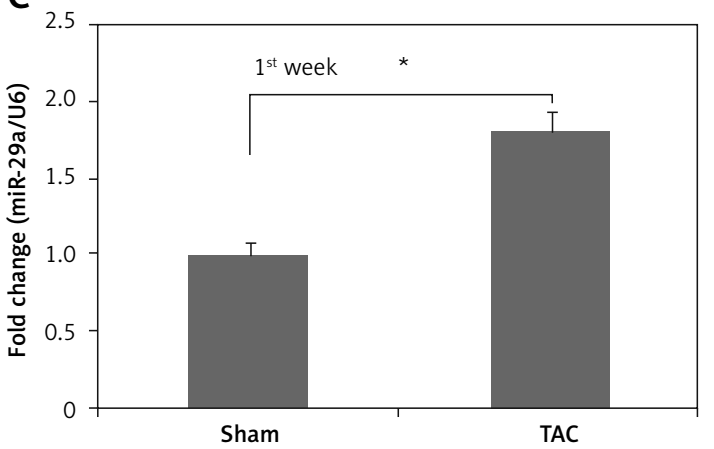

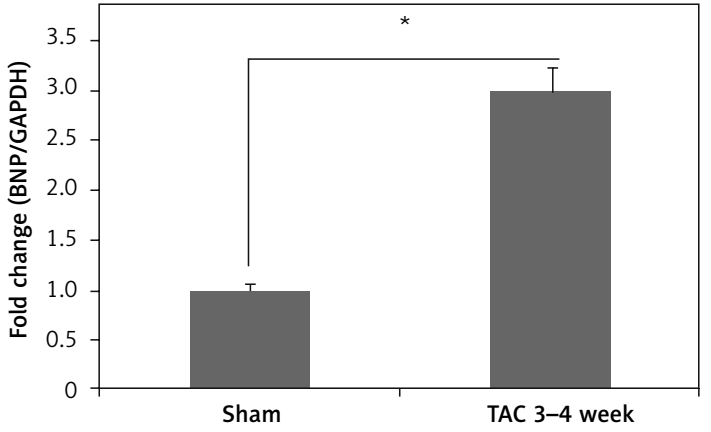

B
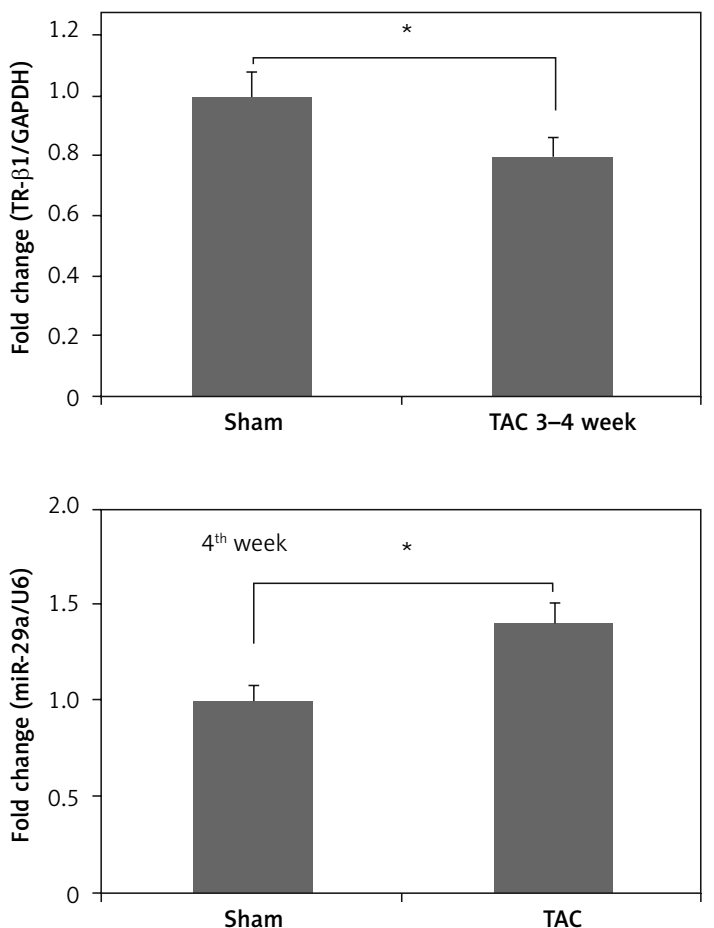

Figure 8. miR-29a is over-expressed in the heart tissue of mice treated with TAC. qRT-PCR analysis showing mRNA expression of ANF, BNP and $\alpha-M H C(A)$, TR- $\beta 1$ mRNA (B) in heart tissues of mice at 3-4 weeks after TAC. C - Fold changes in expression of miR-29a in heart tissues of sham and TAC mice at 1 week and 4 weeks after TAC

The results are means $\pm S E\left({ }^{*} p<0.05,{ }^{* *} p<0.01,{ }^{* * *} p<0.001\right)$.

rat ventricular myocytes. These results suggested that miR-29a can regulate the thyroid hormone pathway by regulating the $\alpha-M H C$ gene via TR- $\beta 1$ in neonatal rat ventricular myocytes. We also evidenced that in absence of triiodothyronine, the upregulation of TR- $\beta 1$ or the miR-29a decoy caused no significant decrease in mRNA or protein levels of $\alpha-M H C$. Previously it has been evidenced that levels of $\alpha-M H C$ can be suppressed by over-expression of TR- $\beta 1$ [33].

In the present study, we showed that in $a b$ sence of tri-iodothyronine, TR- $\beta 1$ up-regulation suppressed the luciferase activity of the $\alpha-M H C$ construct, having the $\alpha-M H C$ promoter sequence, but did not suppress the $\alpha-M H C$ protein and mRNA levels. It was speculated that there may be some other factors which may up-regulate the expression of $\alpha-M H C$ in the absence of triiodothyronine outside the promoter region of $\alpha-\mathrm{MHC}$ involved in the study. We observed that in serum or triiodothyronine deprived conditions, TR- $\beta 1$ showed a weak effect on $\alpha-M H C$, whereas in serum enriched conditions TR- $\beta 1$ changed the $\alpha-M H C$ levels significantly, which suggested that some factors present in serum could regulate the expression of the $\alpha-M H C$ gene via TR- $\beta 1$. The medium enriched with serum was found to have tri-iodothyronine at levels ranging from 1 to $0.1 \mathrm{nM}$. As per the reports published earlier, at levels of $1 \mathrm{nM}$ tri-iodothyronine could alter the mRNA levels of $\alpha-M H C$ [33]. These results indicate that the presence of tri-iodothyronine in serum could regulate the expression of $\alpha-M H C$ by 
miR-29a; additionally there may be a possibility of some other factors being involved in regulation of the $\alpha-M H C$ gene.

In the present study, the role of miR-29a was also elucidated in an animal model. It was evidenced that at the stage of ES cell differentiation, the expression of miR-29a increased along with $\alpha-M H C$ mRNA and was associated with down-regulation of protein levels of TR- $\beta 1$. Additionally, miR-29a was over-expressed in cardiac myocytes [34]. This finding means that miR-29a could be associated with regulation of $\alpha-M H C$ during differentiation of ES cells, which may play an important role in development of the heart, also indicating the involvement of factors other than miR-29a in regulation of TR- $\beta 1$ during the process of ES differentiation to cardiac cells in development of cardiac tissues.

In this study, using the TAC-induced C57 black/6 Jacksonian mice we found that both miR-29a and $\alpha-M H C$ were over-expressed along with down-regulation of TR- $\beta 1$. The up-regulation of miR-29a in neonatal rats' ventricular myocytes seemed to elevate the expression of $\alpha-M H C$ directly rather than inducing cardiac pathological conditions. These outcomes suggested that over-expression of miR29 a was stress-induced, through cardiac hypertrophy and increased levels of $\alpha-M H C$ via TR- $\beta 1$. However, it was still unclear whether the deregulation of TR- $\beta 1$ affected the heart pathophysiology, as the TR- $\beta 1$ deficient mice have been reported to possess normal cardiac function [35]. However, the TR- $\beta 1$ knockout mice do not bind with tri-iodothyronine associated with decreased contractile function [36]. Hence, the tri-iodothyronine pathway through the TR- $\beta 1$ may be important under the stress conditions and the over-expression of miR-29a in mice might affect the function of the heart. Further evaluation is needed to determine the precise functioning of TR- $\beta 1$ in cardiac pathophysiology.

In conclusion, miR-29a can modulate the expression of $\alpha-M H C$ by targeting TR- $\beta 1$ in neonatal rats' ventricular myocytes. Also the over-expression of miR-29a in cardiac hypertrophy appears to increase expression of $\alpha-M H C$ through TR- $\beta 1$.

\section{Acknowledgments}

Chengbin Wang amd Ru He contributed to this work equally.

\section{Conflict of interest}

The authors declare no conflict of interest.

\section{References}

1. Szemraj-Rogucka Z, Szemraj J, Masiarek K, Majos A. Circulating microRNAs as biomarkers for myocardial fi- brosis in patients with left ventricular non-compaction cardiomyopathy. Arch Med Sci 2019; 15: 376-84.

2. Schickel R, Boyerinas B, Park SM, Peter ME. MicroRNAs: key players in the immune system, differentiation, tumorigenesis and cell death. Oncogene 2008; 27: 5959-74.

3. van Rooij E, Sutherland LB, Qi X, Richardson JA, Hill J, Olson EN. Control of stress-dependent cardiac growth and gene expression by a microRNA. Science 2007; 316 : 575-9.

4. Chen JF, Murchison EP, Tang R, et al. Targeted deletion of Dicer in the heart leads to dilated cardiomyopathy and heart failure. Proc Natl Acad Sci USA 2008; 105: 2111-6.

5. da Costa Martins PA, Bourajjaj M, Gladka M, et al. Conditional dicer gene deletion in the postnatal myocardium provokes spontaneous cardiac remodeling. Circulation 2008; 118: 1567-76.

6. Cheng Y, Ji R, Yue J, et al. MicroRNAs are aberrantly expressed in hypertrophic heart: do they play a role in cardiac hypertrophy? Am J Pathol 2007; 170: 1831-40.

7. Sayed D, Hong C, Chen IY, Lypowy J, Abdellatif M. Micro-RNAs play an essential role in the development of cardiac hypertrophy. Circ Res 2007; 100: 416-24.

8. Sucharov C, Bristow MR, Port JD. miRNA expression in the failing human heart: functional correlates. J Mol Cell Cardiol 2008; 45: 185-92.

9. Tatsuguchi M, Seok HY, Callis TE, et al. Expression of microRNAs is dynamically regulated during cardiomyocyte hypertrophy. J Mol Cell Cardiol 2007; 42: 1137-41.

10. Thum T, Galuppo P, Wolf C, et al. MicroRNAs in the human heart: a clue to fetal gene reprogramming in heart failure. Circulation 2007; 116: 258-67.

11. Zhao Y, Ransom JF, Li A, et al. Dysregulation of cardiogenesis, cardiac conduction, and cell cycle in mice lacking miRNA-1-2. Cell 2007; 129: 303-17.

12. Liu N, Bezprozvannaya S, Williams AH, et al. microRNA133a regulates cardiomyocyte proliferation and suppresses smooth muscle gene expression in the heart. Genes Dev 2008; 22: 3242-54.

13. Weiss A, Leinwand LA. The mammalian myosin heavy chain gene family. Annu Rev Cell Dev Biol 1996; 12: 417-39.

14. Callis TE, Pandya K, Seok HY, et al. MicroRNA-208a is a regulator of cardiac hypertrophy and conduction in mice. J Clin Invest 2009; 119: 2772-86.

15. Ojamaa K, Klemperer JD, MacGilvray SS, Klein I, Samarel A. Thyroid hormone and hemodynamic regulation of beta-myosin heavy chain promoter in the heart. Endocrinology 1996; 137: 802-8.

16. Galli E, Pingitore A, lervasi G. The role of thyroid hormone in the pathophysiology of heart failure: clinical evidence. Heart Fail Rev 2010; 15: 155-69.

17. Dillmann W. Cardiac hypertrophy and thyroid hormone signaling. Heart Fail Rev 2010; 15: 125-32.

18. Divakaran V, Mann DL. The emerging role of microRNAs in cardiac remodeling and heart failure. Circ Res 2008; 103: 1072-83.

19. Hasegawa K, Meyers MB, Kitsis RN. Transcriptional coactivator p300 stimulates cell type-specific gene expression in cardiac myocytes. J Biol Chem 1997; 272: 20049-54.

20. Rockman HA, Ross RS, Harris AN, et al. Segregation of atrial-specific and inducible expression of an atrial natriuretic factor transgene in an in vivo murine model of cardiac hypertrophy. Proc Natl Acad Sci USA 1991; 88: 8277-81.

21. Pall GS, Codony-Servat C, Byrne J, Ritchie L, Hamilton A. Carbodiimide-mediated cross-linking of RNA to nylon 
membranes improves the detection of siRNA, miRNA and piRNA by Northern blot. Nucleic Acids Res 2007; 35: e60.

22. Takaya T, Ono K, Kawamura T, et al. MicroRNA-1 and microRNA-133 in spontaneous myocardial differentiation of mouse embryonic stem cells. Circ J 2009; 73: 1492-7.

23. van Rooij E, Sutherland LB, Qi X, Richardson JA, Hill J, Olson EN. Control of stress-dependent cardiac growth and gene expression by a microRNA. Science 2007; 316: 575-9.

24. Carè A, Catalucci D, Felicetti F, et al. MicroRNA-133 controls cardiac hypertrophy. Nat Med 2007; 13: 613-8.

25. Ebert MS, Neilson JR, Sharp PA. MicroRNA sponges: competitive inhibitors of small RNAs in mammalian cells. Nat Methods 2007; 4: 721-6.

26. Ono K, Iwanaga Y, Horie T, et al. MicroRNA-15b modulates cellular ATP levels and degenerates mitochondria via Arl2 in neonatal rat cardiac myocytes. J Biol Chem 2010; 285: 4920-30.

27. Gupta MP. Factors controlling cardiac myosin-isoform shift during hypertrophy and heart failure. J Mol Cell Cardiol 2007; 43: 388-403.

28. Kinugawa K, Yonekura K, Ribeiro RC, et al. Regulation of thyroid hormone receptor isoforms in physiological and pathological cardiac hypertrophy. Circ Res2001; 89: 591-8.

29. Danzi S, Ojamaa K, Klein I. Triiodothyronine-mediated myosin heavy chain gene transcription in the heart. Am J Physiol Heart Circ Physiol 2003; 284: H2255-62.

30. Chen J, Murchison EP, Tang R, et al. Targeted deletion of Dicer in the heart leads to dilated cardiomyopathy and heart failure. Proc Natl Acad Sci USA 2008; 105: 2111-6.

31. Qi M, Ojamaa K, Eleftheriades EG, Klein I, Samarel AM. Regulation of rat ventricular myosin heavy chain expression by serum and contractile activity. Am J Physiol 1994; 267: C520-8.

32. Ebert MS, Neilson JR, Sharp PA. MicroRNA sponges: competitive inhibitors of small RNAs in mammalian cells. Nat Methods 2007; 4: 721-6.

33. Kinugawa K, Minobe WA, Wood WM, et al. Signaling pathways responsible for fetal gene induction in the failing human heart: evidence for altered thyroid hormone receptor gene expression. Circulation 2001; 103: 1089-94.

34. Sassi Y, Avramopoulos P, Ramanujam D, et al. Cardiac myocyte miR-29 promotes pathological remodeling of the heart by activating Wnt signaling. Nat Commun 2017; 8: 1614

35. Gloss B, Trost S, Bluhm W, et al. Cardiac ion channel expression and contractile function in mice with deletion of thyroid hormone receptor alpha or beta. Endocrinology 2001; 142: 544-50.

36. Swanson EA, Gloss B, Belke DD, Kaneshige M, Cheng SY, Dillmann WH. Cardiac expression and function of thyroid hormone receptor beta and its PV mutant. Endocrinology 2003; 144: 4820-5. 